At Westbrook Seminary, a private city school, the athletes are slightly below the others. At Hebron Academy, the largest in Maine, the athletes, for a period of three years, fell five per cent. below the non-athletes. In all the secondary schools for which I have trustworthy records, the athletes fall lower, but never more than five per cent. lower, than other students.

These facts regarding the relative scholarship of athletes and non-athletes cover the records of about two thousand students in six institutions for five years. The facts were gathered by twenty men of varied opinions on the question, who were not endeavoring to make the figures prove any theory or support any opinion. So far as the facts go, they are authentic. They overthrow two thirds of the a priori assumptions regarding the excessive injury of intercollegiate games to the scholarship of the men who play.

Bowdorn CoLlege,

William Trufant Foster.

Brunswick, Maine.

\section{NOTE ON THE YPSILOID APPARATUS OF CRYPTOBRANCHUS.}

A DESCRIPTION of this cartilage in a recent article by Whipple ('The Ypsiloid Apparatus of Urodeles,' Biol. Bull., May, 1906) differs radically from the description by Reese ("The Anatomy of Cryptobranchus,' American Naturalist, April, 1906). According to Whipple the cartilage has the typical $Y$-shape common to urodeles, being bifurcated at the anterior end; according to Reese it is rod-shaped. Having an abundance of material at my disposal, I examined this apparatus in a number of specimens. In every case the cartilage is $\mathrm{Y}$-shaped, but with a marked difference in the structure of the anterior and posterior regions: the posterior portion, forming the stem of the $\mathrm{Y}$, consists of a stout rod of cartilage; the expanded $\mathrm{V}$-shaped anterior portion is very thin. In a dry preparation this thin expanded anterior portion would probably shrivel up and might be easily detached and hence overlooked; the remaining portion would then answer the description given by Reese. It is evident that in its entirety this apparatus has the typical urodele form.

B. G. Sмiтн.

\section{ZOOLOGICAT. Laboratory, UNIVERSITY OF MICHIGAN, ANN ARbor, Mich.}

\section{A NEWLY-FOUND STONY METEORITE.}

THE writer has received notice from a correspondent in Alabama of the finding, near Selma, in that state, of a heretofore undescribed meteorite. The mass is reported as weighing upwards of 300 pounds, and is of Brezina's kugel chondrite type, much resembling the well-known stone from Tieschitz, in Moravia. It will be known as the Selma, Alabama, stone. A detailed description will be published later.

Geo. P. Merrill.

SPECIAL ARTICLES.

THE GREAT CATALOGUE AND SCIENTIFIC INVESTIGATION OF THE HEBER R. BISHOP COLLECTION OF JADE. ${ }^{1}$

Three years ago, on January 3, 1903, it was my sad duty to read before this section of the American Association for the Adrancement of Science, at its meeting in Washington, a notice of the death of Mr. Heber R. Bishop, accompanied by a brief description of his remarkable collection of jade objects (see Amer. Anthropologist, N. S., Vol. 5, JanuaryMarch, 1903, pp. 111-117). See also the Metropolitan Museum Bulletin for May, 1906."

Since that time this magnificent collection, which was presented by Mr. Bishop during his lifetime to the Metropolitan Museum of Art, in New York, has been arranged and installed. He made a large donation for this purpose, and had had prepared and fitted up for its suitable exhibition the northeast room on the second floor of the new wing of the museum

${ }^{1}$ Read before the American Association for the Advancement of Science, New Orleans meeting, December 31, 1905.

${ }^{2}$ See the printed catalogue of the Heber $\mathbf{R}$. Bishop Collection of Jade. By George F. Kunz. Occasional Notes No. 2, Bull. Metropolitan Museum of Art, May, 1906, pp. 1-8. 8vo. Three illustrations. 